\title{
Sobre o bom uso da razão na profissão de fé do vigário saboiano
}

\author{
About the good use of reason in the profession of faith of a \\ savoyard vicar
}

Gustavo Cunha Bezerra ${ }^{1}$

\section{Resumo}

Este artigo toma como ponto de partida os questionamentos defrontados por Rousseau a respeito da existência de Deus e, consequentemente, dos princípios da moral. O resultado desse processo é exposto na Profissão de fé do Vigário saboiano, texto inserido no livro IV do Emílio. A fim de definir seu posicionamento referente aos problemas fundamentais da metafísica, o bom uso da razão, que parece resgatar o modelo cartesiano, torna-se indispensável, principalmente quando se trata de buscar estabelecer um procedimento capaz de oferecer boas respostas para questões tão importantes. Apesar do desprezo pelos sistemas filosóficos anunciado nas primeiras páginas da Profissão de fé, Rousseau não deixa de construir, à sua maneira, um sistema metafísico, tendo em vista que o pensamento desenvolvido pelo Vigário gira em torno desses grandes temas da metafísica que são a imortalidade da alma, a existência de Deus e a liberdade do homem.

Palavras-chave: Razão; Religião; Rousseau.

\section{Abstract}

This article takes as starting point the questions confronted by Rousseau regarding the existence of God and, consequently, the principles of morality. The result of that process is exposed in the Profession of Faith of a Savoyard Vicar, text inserted in Emile's book IV. In order to define his positioning regarding the fundamental problems of the metaphysics, the good use of reason, that seems to rescue the Cartesian's model, becomes indispensable, mainly when it is looking for to establish a procedure capable to offer good answers for such important subjects. In spite of the contempt for the philosophical systems announced in the first pages of the Profession of faith, Rousseau doesn't stop building, in his own way, a metaphysical system, considering that the thought developed by the Vicar

\footnotetext{
${ }^{1}$ Professor de Filosofia da Universidade Estadual da Paraíba.
} 
Religare, ISSN: 19826605, v.15, n.2, dezembro de 2018, p.548-569.

rotates in lathe of those great themes of the metaphysics that are the immortality of the soul, the existence of God and the man's freedom.

Key-words: Reason; Religion; Rousseau.

\section{Introdução}

Poucos dias após a publicação do Emílio, posto à venda em 24 de maio de 1762, no Palais-Royal, em Paris, as poucas dezenas de páginas que compõem a Profissão de fé farão escândalo² . A reação, entretanto, não virá apenas da Igreja e do Parlamento, mas também de muitos filósofos, revelando mais uma vez o caráter polemista de Rousseau (vale lembrar a forte polêmica levantada uma década antes pelo Discurso sobre as ciências e as artes). Voltaire, por exemplo, símbolo do filósofo engajado contra a intolerância religiosa, publica anonimamente o Sentiment des citoyens, texto no qual ele finge ser um calvinista furioso com a publicação do Emílio pedindo que este livro, e o seu autor, fossem condenados em Genebra.

A princípio, pode-se dizer que a causa do escândalo em torno da publicação do Emílio deve-se ao fato de que, ao mesmo tempo em que faz duras críticas aos abusos das religiões, particularmente ao catolicismo, quando nega o pecado original e questiona a Revelação, o autor da Profissão de fé do Vigário saboiano opõe-se categoricamente ao materialismo ateu de Helvétius e Diderot, e

\footnotetext{
2 Bernardi (2010, p. 12) descreve a rapidez com que se desenrolam as condenações ao livro no qual está inserido a Profissão de fé do Vigário saboiano: “O Emílio é confiscado do livreiro Duchesne já no dia 3 de junho, depois condenado na Sorbonne no dia 7 e pelo Parlamento de Paris no dia 9; no mesmo dia, Rousseau, decretada sua prisão, foge para a Suíça. (...) Em 11 de junho, enquanto se queima o Emílio em Paris, o confiscam em Genebra, e no dia 19, Rousseau é igualmente objeto de um mandado de captura do petit conseil da República".

Outra interessante observação de Bernardi refere-se à repercussão dessa obra. Depois do escândalo provocado pelos dois primeiros Discursos, a publicação do Emílio desperta uma enorme atenção no mundo das letras, que pode ser traduzida em números. Enquanto as primeiras obras de Rousseau, entre 1751 e 1762, haviam gerado cento e noventa e dois títulos de comentários sobre o autor, "depois de 1762, assiste-se a uma verdadeira explosão, para atingir, em 1799, mil e noventa e dois títulos. É ao Emílio que se deve atribuir essa avalanche de textos, dos quais dois terços se referem à filosofia religiosa de Rousseau, portanto, à Profissão de fé" (BERNARDI, 2010, p. 13).
} 
Religare, ISSN: 19826605, v.15, n.2, dezembro de 2018, p.548-569.

defende a existência de um Deus bom e justo que é a causa da ordem na natureza e fonte dos princípios morais. Bernardi (2010) aponta para essa "coerência singular" do pensamento de Rousseau como o alvo das críticas sofridas pela Profissão de fé:

O "partido filosófico", do qual Voltaire é o chefe autoproclamado e reconhecido, reage tão vivamente não porque Rousseau afirma sua crença religiosa, mas porque ele pretende fazê-lo em nome de sua razão. $\mathrm{O}$ arcebispo de Paris fulmina mais ainda contra aquele que se diz crente, cristão, e que recusa a autoridade, do que contra o incrédulo. (2010, p. 15)

Não deixa de ser surpreendente que Rousseau tenha se tornado um adversário comum aos partidos opostos, o que torna qualquer tentativa de classificar o genebrino como defensor desse ou daquele partido uma tarefa que está sempre sujeita a objeções. Mais uma dentre as diversas controvérsias em torno do pensamento rousseauniano: seria ele sentimentalista religioso, como defende Masson, ou racionalista, como o quer Derathé? Estaria ele mais próximo dos religiosos ou dos filósofos? Não se pretende responder diretamente aqui tais questionamentos, mas não é possível desconsiderá-los, na medida em que definem uma importante temática quando se discute o pensamento metafísico e religioso de Rousseau.

No proclamado combate ao materialismo, o primeiro problema a ser enfrentado pelo Vigário saboiano é o da existência da substância imaterial. É necessário, antes de tudo, demonstrar que a matéria não é a única substância. Apesar do inquestionável sensualismo de Rousseau ${ }^{3}$, discípulo de Locke e Condillac, ele discorda categoricamente de Helvétius, que afirma que pensar e sentir são a mesma coisa. Para Rousseau, o julgamento não pode ser reduzido à passividade das sensações, o que lhe permite concluir que o ser ativo que julga distingue-se da matéria.

\footnotetext{
${ }^{3} \mathrm{O}$ que se evidencia ao lembrar a importância atribuída por Rousseau às experiências sensoriais nos primeiros livros do Emílio.
} 
Religare, ISSN: 19826605, v.15, n.2, dezembro de 2018, p.548-569.

Outra divergência em relação ao materialismo refere-se à origem do movimento, a qual não poderia também ser atribuída à própria matéria. Para o Vigário, essa causa é encontrada na vontade: “os corpos inanimados não agem senão pelo movimento, e não existe verdadeira ação sem vontade". A vontade, que é a causa do movimento nos corpos animados, é também a causa primeira do movimento do universo, o primeiro motor: "uma vontade move o universo e ainda a natureza" (OC IV, p. 576)4, eis o primeiro dogma (ou artigo de fé) do Vigário saboiano.

Os movimentos existentes no universo e na natureza aparecem, aos olhos do Vigário, como perfeitamente ordenados, em que “cada peça é feita para as outras" (OC IV, p. 578). A causa dessa ordem observada só pode ser atribuída a uma vontade inteligente: "Se a matéria movida me mostra uma vontade, a matéria movida segundo certas leis me mostra uma inteligência" (OC IV, p. 578). Essa passagem da Profissão de fé, que constitui o segundo artigo de fé, visa demonstrar a existência de Deus, na medida em que a vontade inteligente que move o universo é única, suprema, enfim, é o próprio Deus.

Em contraste com a ordem da natureza, a desordem da sociedade evidencia, para o Vigário, a ideia de alma, que permite ao homem agir livremente em desacordo com a natureza, mas que torna possível também sua elevação ao belo moral. A atividade da alma que se contrapõe às paixões deriva da liberdade do homem, pois "o princípio de toda ação está na vontade de um ser livre". O terceiro artigo de fé do Vigário saboiano articula justamente essa relação entre a alma e a liberdade: "o homem é então livre em suas ações e como tal, animado de uma substância imaterial" (OC IV, p. 586).

Esses princípios, resumidos muito brevemente acima, o Vigário consegue extrair a partir do "bom uso da razão", que reflete adequadamente sobre aquilo que ele observa na natureza, mas que é capaz igualmente de reconhecer os seus

\footnotetext{
4 Todas as referências às obras de Rousseau remetem às Oeuvres completes, Bibliothèque de la Pléiade, 5 vols, 1959-1995. Nas citações indico o número do volume e a página.
} 
Religare, ISSN: 19826605, v.15, n.2, dezembro de 2018, p.548-569.

limites e, dessa forma, deixar à consciência o papel de decidir sobre o que a razão é impossibilitada de resolver.

Apesar do desprezo pelos sistemas filosóficos anunciado nas primeiras páginas da Profissão de fé, Rousseau não deixa de construir, à sua maneira, um sistema metafísico, tendo em vista que o pensamento desenvolvido pelo Vigário gira em torno desses grandes temas da metafísica que são a imortalidade da alma, a existência de Deus e a liberdade do homem.

São estes argumentos que permitem Rousseau enfrentar as inquietantes dúvidas a respeito da existência de Deus e, consequentemente, dos princípios universais da moral. O resultado desse processo foi exposto na Profissão de fé do Vigário saboiano, texto inserido no livro IV do Emílio. A fim de definir seu posicionamento referente aos problemas fundamentais da metafísica, o bom uso da razão, que parece resgatar o modelo cartesiano, torna-se indispensável, principalmente quando se trata de saber quais são as questões que realmente importam para o conhecimento humano.

\section{Do ceticismo à apreensão da verdade}

No verbete Pirro, do Dicionário Histórico e Crítico, Bayle se reporta ao pensamento de La Mothe de Vayer a respeito do pirronismo. Contrariamente ao juízo comum dos teólogos, La Mothe de Vayer defende a ideia de que o pirronismo é de grande valia para a fé cristã, pois, ao reconhecer que a razão conduz o homem a um labirinto sem saída, o cético aceita a ignorância humana e, assim, pode acolher mais tranquilamente os mistérios do cristianismo. Lemos no texto de Bayle que:

Se estiver convencido que nada de bom lhe é prometido em suas discussões filosóficas, um homem se sentirá mais disposto a rogar a Deus, a pedir-lhe a persuasão das verdades em que se devem crer, do que se ele se gaba de um bom sucesso raciocinando e disputando. Conhecer os defeitos da razão é, portanto, uma feliz disposição para a fé. (BAYLE, 2007, p. 159) 
Religare, ISSN: 19826605, v.15, n.2, dezembro de 2018, p.548-569.

Mesmo que Rousseau tenha outra concepção sobre o pirronismo, em certo sentido até mesmo contrária à de La Mothe Voyer, não há como deixar de perceber a semelhança das palavras citadas acima com a crítica à filosofia que inicia a Profissão de fé e, por fim, com o desfecho da narrativa do Vigário saboiano que termina por aceitar de bom grado os mistérios da religião.

Nas primeiras páginas da Profissão de fé, o Vigário expressa o estado de espírito em que se encontrava após ser punido injustamente. Todas as verdades que havia aceitado desde a infância, quando seus pais decidiram pela sua "profissão de padre", estavam agora desacreditadas. Essa experiência conduz o jovem padre ao completo ceticismo:

Vendo por tristes observações serem invertidas as minhas ideias sobre o justo, o honesto e todos os deveres do homem, eu perdia a cada dia alguma das opiniões que recebera; (...) pouco a pouco percebi que se obscurecia em meu espírito a evidência dos princípios (...). Eu estava naquelas disposições de incerteza e de dúvida que Descartes exige para a procura da verdade. (...)

Eu meditava, pois, sobre a triste sorte dos mortais, que flutuam no mar das opiniões humanas, sem leme, sem bússola, e entregues às suas tempestuosas paixões, sem mais guia do que um piloto inexperiente que ignora sua rota e não sabe nem de onde vem nem aonde vai. Pensava comigo mesmo: amo a verdade, procuro-a, mas não posso reconhecê-la; mostrem-na e permanecerei ligado a ela; por que se furta ela à solicitude de um coração feito para adorá-la?

(...) errando de dúvida em dúvida, eu só tirava de minhas longas meditações incertezas, obscuridade e contradições sobre a causa de meu ser e sobre a regra de meus deveres. (OC IV, p. 567)

Olaso (1980) classifica esse momento de crise, que inicia a Profissão de fé, como uma crise pirrônica, a qual é definida pela multiplicidade de apresentações com as quais se depara o cético na sua busca pela verdade. $O$ pirrônico percebe que as opiniões contrárias são equivalentes (isosthéneia), tanto devido à variedade de apresentações, como à vaidade das opiniões. Na sua busca pela verdade, o pirrônico deseja apenas alcançar a serenidade, e como sabe que são exatamente as discussões filosóficas as causas das perturbações, decide então pela epoké, a 
Religare, ISSN: 19826605, v.15, n.2, dezembro de 2018, p.548-569.

suspensão dos juízos. Segundo Olaso, a superação da crise pirrônica vivida pelo Vigário ocorrerá através da adoção de um tipo de pensamento que se assemelha ao "ceticismo acadêmico", ou seja, aquele que percebe "a incerteza a respeito dos primeiros princípios do ser e do conhecer, acompanhada de uma aguda consciência do que então se denominou 'os limites do espírito humano'" (OLASO, 1980, p. 11). O cético acadêmico, assim como o pirrônico, também deseja a tranquilidade, "entretanto, admite critérios, se não racionais, ao menos razoáveis, e substitui o problema da verdade (a presença da physis) pelo da verossimilhança (o assentimento mitigado à opinião mais razoável)" (OLASO, 1980, p. 11). Ao realizar as reflexões que compõem a Profissão de fé, o Vigário concluirá que é preferível admitir uma verdade, mesmo que ela seja apenas provável, do que permanecer eternamente em dúvida sobre as questões fundamentais da existência. Nesse momento, o critério utilizado pelo padre para se decidir será o de tomar a opinião "que explica tudo" e que oferece menos dificuldades que as demais. Nas palavras de Sébastien Charles, esse ceticismo acadêmico do Vigário:

é resultado de um longo processo, no qual se distingue o que pode ser sabido daquilo que não poderá sê-lo; ignorância que não impede nem a reflexão, nem a ação, e que permite rejeitar o ceticismo pirroniano como incompatível com a natureza humana, incapaz de se satisfazer com a absoluta falta de certeza (2009, p. 25-6).

A causa do turbilhão de ideias que impede o homem de encontrar uma verdade estável consiste exatamente na "insuficiência do espírito humano" (OC IV , p. 567). Tal constatação conduz à recusa das opiniões dos filósofos e à revisão geral das ideias até então aceitas:

Então, repassando no espírito as diversas opiniões que me haviam alternadamente arrebatado desde o nascimento, vi que, embora nenhuma delas fosse bastante evidente para produzir imediatamente a convicção, tinham graus diversos de verossimilhança e o assentimento interior prestava-se ou recusava-se a elas em diferentes medidas. (OC IV, p. 569) 
Religare, ISSN: 19826605, v.15, n.2, dezembro de 2018, p.548-569.

Nos Devaneios do caminhante solitário, Rousseau relata o período de crise, no qual as antigas certezas não lhe pareciam mais tão seguras, fato que exigia a resolução das dúvidas emergentes e a definição de uma "regra fixa de conduta": "resolvi submeter meu íntimo a um exame severo que o determinasse para o resto de minha vida assim como desejaria encontrá-lo no momento de minha morte" (OC I, p. 1015). A necessidade de encontrar alguma certeza, a partir das suas próprias reflexões, conduz Rousseau a realizar "um empreendimento filosófico que não deixa de lembrar o procedimento cartesiano, destinado a estabelecer princípios seguros para evitar toda forma de ceticismo" (CHARLES, 2009 , p. 25). Nesse processo de revisão das ideias, crenças e opiniões - no embate entre os pensamentos filosóficos que Rousseau aceita e aqueles que ele rejeita percebe-se a influência de Descartes nos argumentos apresentados pelo Vigário saboiano.

Influência que pode ser encontrada já na juventude de Jean-Jacques, quando, em Charmettes, dedicava-se intensamente aos estudos de filosofia ${ }^{5}$. Dentre as leituras que então realizava, constavam a "Lógica de Port-Royal, o Ensaio de Locke, Malebranche, Leibniz, Descartes etc." (Confissões, OC I, p. 237). No poema Le Verger de Mme. la Barone de Warens (OC II, p. 1.128), escrito provavelmente em 1737, Rousseau expressa suas primeiras impressões sobre o pensamento de Descartes:

Tantôt à la Physique appliquant mes problèmes, Je me laisse entraîner à l'esprit de systèmes : Je tâtonne Descartes et ses égarements Sublimes, il est vrai, mais frivoles Romans ${ }^{6}$.

\footnotetext{
${ }^{5}$ Sobre esse importante período de formação filosófica, mas também religiosa, de Jean-Jacque Rousseau, são indispensáveis as análises realizadas por Masson no capítulo IV, intitulado "L'autodidacte et son 'Magasin d'idées'", do livro La formation religieuse de Rousseau, vol.1. Conferir igualmente o livro VI das Confissões.

6 "Às vezes aplicando a física aos meus problemas / Eu me deixo levar pelo espírito de sistemas / Eu sondo Descartes e seus delírios / Sublimes, certamente, mas frívolos romances". Julgamento claramente inspirado nas Cartas filosóficas de Voltaire que, na Carta XIV, Sobre Descartes e Newton, escreve: “A Geometria era um guia (...) que o teria [Descartes] conduzido seguramente em sua Física; entretanto, ele abandonou, no fim, esse guia e se entregou ao espirito de sistema; então sua
} 
Religare, ISSN: 19826605, v.15, n.2, dezembro de 2018, p.548-569.

Não podemos, evidentemente, classificar Rousseau como um cartesiano, pelo contrário, ele é um filósofo do século XVIII que adere às ideias de seu tempo, as quais se voltam frequentemente contra a filosofia do século XVII, principalmente a de Descartes (as leis dos corpos, de Newton, suplantam a física dos turbilhões, e a história das ideias, de Locke, tornam as ideias inatas inviáveis $)^{7}$. Entretanto, mesmo que não tenha aderido ao cartesianismo, quando Rousseau organiza seu pensamento em oposição aos seus amigos filósofos, os “missionários de Ateísmo", ele encontra em Descartes um modelo.

Inquieto, mas não convencido pelas doutrinas materialistas, Rousseau não consegue responder razoavelmente aos argumentos dos philosophes que, longe de ajudarem a resolver suas dúvidas, contribuíram apenas para abalar "todas as certezas que eu acreditava ter sobre os pontos que mais me importava conhecer" (OC I, p. 1.015). O genebrino, movido pelo sentimento religioso - do qual ele diz nunca ter se afastado completamente ${ }^{8}$-, busca alguma resposta capaz de expressar e sustentar adequadamente seu pensamento a respeito de Deus. Gouhier vê, nesse embate, a origem da dissociação entre "entendimento" e "consciência" estabelecida pelo Vigário: "Rousseau se sente estúpido quando escuta os discursos incrédulos de 'filósofos' como Diderot, Grimm, D'Holbach; as certezas de seu coração suportam mal o transtorno de sua razão" (2005, p. 53).

Se a Profissão de fé pode ser entendida como um ordenamento intelectual, que permite ao autor livrar-se da inquietação originada pelo ateísmo de alguns philosophes, pode-se afirmar que, na origem desse processo, Rousseau encontra

Filosofia foi apenas um romance engenhoso (...) Mas não é demais dizer que ele era estimável mesmo nos seus delírios [égarements]" (VOLTAIRE apud GOUHIER, 2005, p. 51).

${ }^{7}$ É importante ressaltar que o pensamento seiscentista não estava totalmente desacreditado no século XVIII. Malebranche, por exemplo, não é esquecido no século das Luzes. Segundo Brehier (1965, p. 88), “o pensamento oratoriano, e especialmente o pensamento malebranchista, permanece bastante vivo no século XVIII, seja na França, seja na Itália".

${ }^{8} \mathrm{Na}$ Carta à M. de Franquières, Rousseau ressalta a constância de sua crença religiosa: "acreditei na infância, por autoridade, em minha juventude, por sentimento, na maturidade, pela razão; agora acredito porque sempre acreditei" (OC IV, p. 1.134). 
Religare, ISSN: 19826605, v.15, n.2, dezembro de 2018, p.548-569.

em Descartes a forma como deveria conduzir seu pensamento. Ele aprende, com o filósofo seiscentista, que a única forma de encontrar algo verdadeiro seria através do enfrentamento racional de suas dúvidas. Rousseau sente a necessidade, portanto, do estabelecimento de uma filosofia que seja a expressão daquilo que lhe permita superar as dúvidas sobre as questões que lhe são essenciais. Esse procedimento é claramente exposto nas Cartas Morais, onde Rousseau aconselha Mme. d'Houdetot a “examinar por uma vez tudo o que pensamos, tudo o que acreditamos, tudo o que sentimos, e tudo o que devemos pensar, sentir e acreditar para sermos felizes na medida em que permite a condição humana" (OC IV, p. 1087).

Certamente, a dúvida mais inquietante para Rousseau refere-se à existência de Deus. Ora, esse questionamento não surge senão através da razão, do pensamento de filósofos ateus, como Diderot. Diante disso, Rousseau irá justificar a partir de sua própria razão seu posicionamento contrário ao ateísmo, e demonstrar para si mesmo que sua crença, embora não seja apoiada exclusivamente na razão, representa aquilo que ele realmente acredita ser verdadeiro.

Se Rousseau sublinha os limites da razão, isso não implica, obviamente, no abandono do recurso à razão. Mesmo porque, na história da filosofia, já era bastante comum o reconhecimento dos limites humanos; como Descartes, que entendia que o caráter finito do homem o impossibilitava de conhecer o infinito. Malebranche segue a mesma ideia, mas, diferentemente de Descartes e de Rousseau, para o oratoriano, quando se trata daquilo que está além do limite da razão, "a humildade intelectual consiste em confiar cegamente na autoridade da Igreja", pois nessas questões ela "se torna única regra do conhecimento" (DERATHÉ, 1948, p. 60). Rousseau, por outro lado, distingue o que é misterioso do que é absurdo e, se admite as crenças que não são insensatas, recusa expressamente aquilo que é contrário à razão como, por exemplo, os milagres e o pecado original. 
Religare, ISSN: 19826605, v.15, n.2, dezembro de 2018, p.548-569.

Nas questões em que a razão não é capaz de se decidir, cabe ao sentimento interior fornecer uma opinião que permita ao genebrino abandonar a dúvida. Segundo Derathé, não se trata de desconfiar da razão, pois "tudo se passa como se a razão, consciente dos seus limites, contestasse a si mesma para nos recomendar o uso do sentimento interior, o único capaz de nos tirar do estado de dúvida, ao qual nós estaríamos condenados se nada viesse suprir a razão vacilante" (1948, p. 65). Enquanto, por um lado, a formulação do sistema metafísico do Vigário obedece a uma rigorosa racionalidade, por outro lado, sua conclusão fundamental - da existência de Deus - pode ser realizada apenas quando se escuta a voz interior, a consciência ${ }^{9}$.

Para o genebrino, não existe felicidade sem o recurso às certezas proporcionadas pela religião, e pode-se entender aqui essa felicidade como "mais próxima da paz, do que do prazer, de uma paz certamente ligada à satisfação, mas que pode também ser somente um apaziguamento ou ausência de perturbação" (VINCENTI, 2006, p. 79), tal como a definem os estoicos e os epicuristas. Na Carta a Voltaire (sobre a Providência), Rousseau expressa sua “incapacidade" de viver sem o socorro à crença em Deus. Mesmo admitindo o caráter insolúvel das dúvidas que podem ser levantadas sobre a existência ou não de Deus, Rousseau diz:

creio em Deus tão fortemente quanto em qualquer outra verdade, porque crer e não crer são as coisas que menos dependem de mim; porque o estado de dúvida é um estado demasiado violento para minha alma; porque, quando minha razão divaga, minha fé não pode permanecer muito tempo em suspenso e se decide sem ela; enfim, porque mil questões me atraem de preferência para o lado mais consolador, e juntam o peso da esperança ao equilíbrio da razão. (OC IV, p. 1.070-1)

Por outro lado, Rousseau compreende perfeitamente que a doutrina religiosa, qualquer que seja, não deve de forma alguma pregar a intolerância. É

\footnotetext{
9 Sobre o tema da consciência, e do seu papel no pensamento rousseauniano, conferir a obra de Derathé citada acima.
} 
Religare, ISSN: 19826605, v.15, n.2, dezembro de 2018, p.548-569.

em torno dessa dificuldade que se deve buscar o objetivo de Rousseau ao expor seu pensamento religioso no livro IV do Emílio. Como observa Groethuysen, “a Profissão de fé do Vigário saboiano não é uma confissão: é um programa. Segundo um exemplo-tipo, o do Vigário, mostra-se como um homem, sem ser intolerante e sem ser filósofo, pode ter uma religião" (apud KAWAUCHE, 2012, p. 95).

Esse "programa", cuja função pedagógica seria a de expor aos homens as questões essenciais da religião, realiza todo um percurso metafísico para mostrar que existe uma vontade que move o universo, que essa vontade é inteligente, que o homem é livre e sua alma é imortal; princípios fundamentais para a felicidade de qualquer um, na visão de Rousseau. Percebe-se aí a estreita relação entre metafísica, religião e moral no pensamento do Vigário saboiano, e seria até mesmo difícil distinguir aqui as duas últimas.

Apesar de todas as críticas e ressalvas de Rousseau à metafísica, a fundamentação da moral e das certezas da religião natural, desenvolvida na Profissão de fé, exige o recurso à metafísica, tendo em vista, principalmente, a concepção metafísica de ordem da natureza ${ }^{10}$ que permite ao Vigário concluir a existência do Deus bom e justo, princípio da ordem moral.

O bom uso da razão orienta inevitavelmente à crença em Deus, esse é um elemento chave no pensamento religioso de Rousseau: “O filósofo que não crê erra, porque emprega mal a razão que cultivou e está em condições de entender as verdades que rejeita" (OC IV, p. 555), afirma o genebrino algumas páginas antes do início da Profissão de fé. O recurso à razão torna-se indispensável para que o homem encontre seu lugar na ordem do universo. Ao homem civilizado não é mais permitido abdicar da reflexão, tal como no estado de natureza:

O homem não começa facilmente a pensar; mas, assim que começa, não para mais. Quem já pensou pensará sempre e, uma vez exercitado na reflexão, o entendimento não poderá mais

10 Apesar da noção de ordem da natureza ser sugerida pela observação dos fenômenos da natureza, tal concepção assume seu caráter fundamental somente quando anuncia metafisicamente a existência de Deus. 
Religare, ISSN: 19826605, v.15, n.2, dezembro de 2018, p.548-569.

permanecer em repouso. (...) O mesmo homem que deve permanecer estúpido nas florestas deve tornar-se razoável e sensato nas cidades. (OC IV, p. 550-1)

Ainda nas páginas que antecedem a narrativa do Vigário saboiano, Rousseau expressa a forma como ele deseja que Emílio se relacione com o mundo: “veja ele pelos olhos, sinta pelo seu coração; não o governe nenhuma autoridade, exceto a de sua própria razão" (OC IV, p. 551). Encontram-se aqui reunidas as fontes do conhecimento para o pensamento rousseauniano: os sentidos, que permitem a apreensão do mundo exterior, o sentimento interior (ou consciência), instinto inato que conduz ao amor da ordem, e a razão, faculdade diretiva das ações humanas e do conhecimento. Cabe ressaltar que a filosofia defendida pelo Vigário desenvolve-se, precisamente, através do pleno acordo entre os sentidos, a consciência e a razão.

Enquanto a educação da infância, no Emílio, privilegia o desenvolvimento dos sentidos, na adolescência, com o despertar das novas inquietações e questionamentos, movido pelo "progresso natural das Luzes", a abstrata ideia de Deus torna-se uma questão fundamental, que precisa ser adequadamente pensada pelo jovem Emílio. Os perigos de equivocar-se nesse assunto, para Rousseau, são, principalmente, o completo ceticismo, por um lado, e o fanatismo intolerante, por outro. A razão, cultivada adequadamente, obedecendo ao "progresso natural das Luzes", evita esse tipo de perigo, pois as conclusões às quais chegará não serão outras senão aquelas que definem a religião natural: "as luzes da razão sozinhas não podem, na escola da natureza, levar-nos mais longe do que à religião natural" (OC IV, p. 635-6). É esse o papel da educação religiosa expressa no livro IV do Emílio, auxiliar o ordenamento das ideias no jovem. Não se trata de uma imposição, mas da apresentação de determinado raciocínio, aquele adotado pelo Vigário, que poderá servir de modelo para o jovem, caso ele 
Religare, ISSN: 19826605, v.15, n.2, dezembro de 2018, p.548-569.

concorde com o que lhe foi exposto ${ }^{11}$. Nesse sentido, é importante lembrar aqui as palavras que abrem a Profissão de fé do Vigário saboiano:

Meu filho, não esperes de mim nem discursos sábios nem profundos raciocínios; não sou um grande filósofo e pouco me preocupo em sê-lo. Mas às vezes tenho bom senso e amo sempre a verdade. Não quero argumentar contigo, nem mesmo tentar convencer-te; basta-me expor-te o que penso na simplicidade de meu coração. Consulta o teu durante o meu discurso, é tudo o que te peço. Se me engano, é de boa-fé; isso basta para que meu erro não seja imputado como crime; mesmo que te enganasse da mesma forma, pouco mal haveria nisso. Se eu pensar bem, a razão é-nos comum e temos o mesmo interesse em escutá-la: por que não pensarias como eu? (OC IV, p. 565)

A concepção de que a razão é comum aos homens e que, assim, possibilita o alcance das mesmas verdades por indivíduos diversos, é bastante conhecida no pensamento cartesiano e Rousseau parece imitar o início do Discurso do Método no qual lemos as seguintes palavras: “o poder de bem julgar e distinguir o verdadeiro do falso, que é propriamente o que se denomina o bom senso ou a razão, é naturalmente igual em todos os homens" (1983, p. 29). Mas é importante notar, como faz Burgelin, que mesmo que a razão nos seja comum, "nossos interesses a escutá-la, nossas possibilidades, não são necessariamente as mesmas" (BURGELIN, 1969, p. 1510). Mesmo que a razão seja comum aos homens, ela não é igualmente distribuída. Tal pensamento pode ser encontrado na Carta a Franquières: "Se eu me enganei não é minha culpa, é da natureza que não deu à minha cabeça uma grande medida de inteligência e de razão" (OC IV, p. 1134).

A crítica à tradição filosófica, logo na primeira frase da exposição do raciocínio do Vigário, revisita uma acusação que Rousseau já havia expressado

\footnotetext{
${ }^{11}$ Tal procedimento, que procura expor a maneira pessoal através da qual o autor procedeu a fim de resolver suas próprias inquietações, assemelha-se bastante às observações iniciais de Descartes no Discurso do Método: "o meu desígnio não é ensinar aqui o método que cada qual deve seguir para bem conduzir a sua razão, mas apenas mostrar de que maneira me esforcei por conduzir a minha" (1983, p. 30).
} 
Religare, ISSN: 19826605, v.15, n.2, dezembro de 2018, p.548-569.

veementemente no Discurso sobre as ciências e as artes. Contrapondo-se à filosofia tradicional, o genebrino toma, de certa forma, a ingênua ignorância como a verdadeira sabedoria ${ }^{12}$. O Vigário concorda plenamente com a constatação de Descartes a respeito da insuficiência da filosofia tradicional na busca pela verdade e, da mesma forma que o célebre filósofo do século XVII, tentará alcançála por si mesmo (OC IV, p. 569):

Compreendi (...) que, longe de me libertar de minhas inúteis dúvidas, os filósofos só fariam multiplicar as que me atormentavam e não resolveriam nenhuma. Tomei, então, um outro guia e disse com meus botões: consultemos a luz interior, desorientar-me-á menos do que eles me desorientam, ou, pelo menos, meu erro será meu e perverter-me-ei menos seguindo minhas próprias ilusões do que me entregando às suas mentiras.

Essa recusa do Vigário aos sistemas filosóficos, entretanto, refere-se a um conjunto mais específico de pensadores. Conforme indica Burgelin, quando Rousseau usa a palavra philosophes, seus alvos seriam "Voltaire, o malabarista (jongleur) Tronchin, Helvétius ou a coterie holbachique, Diderot e a Enciclopédia, o deísmo estéril deles, o materialismo confesso ou oculto deles, a doutrina da dupla verdade que transforma a argumentação em disfarce" (1973, p. 42). Os discursos dos filósofos não visam, de fato, a verdade; o objetivo de cada um deles é essencialmente se distinguir dos outros: “onde está o filósofo que, por sua glória, não enganaria de bom grado o gênero humano?" (OC IV, p. 569), questiona-se o Vigário.

\footnotetext{
${ }^{12} \mathrm{O}$ elogio à ignorância, que toma Sócrates como modelo, é recorrente na história do pensamento ocidental. Nicolau de Cusa, segundo Gouhier, atribuiu o nome Idiota àquele cujo "não-saber é um saber, no qual a não-cultura preservou a ingenuidade, no qual a ignorância é douta ignorância" (2005, p. 62). Sobre esse elogio em Descartes, Gouhier cita duas passagens expressivas, a primeira delas extraída da 6a parte do Discurso do Método, onde Descarte defende a escolha do idioma francês para publicação do seu livro: "Se escrevo em francês, que é a língua de meu país e não em latim, que é a de meus preceptores, é porque espero que aqueles que se servem apenas de sua razão natural inteiramente pura julgarão melhor minhas opiniões do que aqueles que não acreditam senão nos livros antigos." (DESCARTES, 1983, p. 71) A outra passagem citada por Gouhier está no prefácio da edição francesa dos Principia: "Aqueles que têm menos aprendido de tudo o que se chamou até aqui Filosofia são os mais capazes de aprender a verdade" (DESCARTES apud GOUHIER, 2005, p. 64).
} 
Religare, ISSN: 19826605, v.15, n.2, dezembro de 2018, p.548-569.

O ponto de apoio dos discursos filosóficos é, para Rousseau, um terreno instável e inseguro. A própria linguagem, instrumento necessário para o raciocínio filosófico, é incapaz e limitada para que se possa pretender expressar através dela a verdade. Enquanto a linguagem primitiva permanecia entregue às paixões e ao presente e, desse modo, estabelecia um vínculo mais próximo com o real, a linguagem do homem civilizado procura ultrapassar as imagens do real através das ideias. A intensificação do comércio entre os homens e o desenvolvimento das luzes afastam a linguagem das paixões; sua função será, a partir de então, cada vez mais racional. As "palavras frias" do homem civilizado, suas "ideias gerais", ou seja, algo "puramente intelectual", o distancia do mundo ao qual está ligado fundamentalmente a partir dos sentidos. Esse é o equivocado ofício da filosofia, que procura alcançar a verdade por meio de discursos artificiais (cf. BURGELIN, 1973, p. 46) ${ }^{13}$.

Tanto a metafísica quanto a ciência são vistas com grande desconfiança por Rousseau, pois ambas procuraram muitas vezes explicar aquilo que foge à capacidade humana de compreender. Suas teorias são constantemente desmentidas. Mesmo o sábio e metódico Descartes, conforme sentencia Rousseau nas Cartas Morais, "ao andar com as maiores precauções acreditou chegar à verdade e encontrou apenas mentiras" (OC IV, p. 1099). A essência das coisas, a causa primeira, é inacessível à razão. Portanto, como observa Burgelin, cabe ao homem se "deter às verdades mais modestas, mas ao nosso alcance, relacionadas às nossas verdadeiras necessidades e experiências, que formam o domínio que nos é permitido explorar" (1973, p. 44). Trata-se, como se refere o Vigário, de "limitar minhas pesquisas ao que me interessava imediatamente (...) e a me inquietar até a dúvida com as coisas que me importava saber" (OC IV, p. 569).

\footnotetext{
${ }^{13}$ Tais comentários de Burgelin fazem referência, certamente, ao Ensaio sobre a origem das línguas, texto no qual podemos ler as seguintes palavras sobre o desenvolvimento da linguagem na história da humanidade: "À medida que crescem as necessidades, que os negócios se complicam, que as luzes se estendem, a linguagem muda de caráter, torna-se mais apropriada e menos apaixonada, substitui as ideias aos sentimentos, não fala mais ao coração mas à razão" (ROUSSEAU, 1998, p. 123).
} 
Religare, ISSN: 19826605, v.15, n.2, dezembro de 2018, p.548-569.

Não temos a medida dessa máquina imensa, não podemos calcular suas relações, não conhecemos nem suas primeiras leis nem sua causa final; (...) mistérios impenetráveis rodeiam-nos por toda a parte; eles estão acima da região sensível; para penetrá-los, acreditamos ter inteligência e só temos imaginação. Através desse mundo imaginário, cada qual abre para si mesmo um caminho que acredita ser o certo; ninguém pode saber se o seu leva à meta. A única coisa que não sabemos é ignorar o que não podemos saber. (...) Parte pequena de um grande todo cujos limites nos escapam e que seu autor entrega a nossas loucas discussões, somos bastante vãos para querer decidir o que é esse todo e o que somos em relação a ele. (OC IV, p. 568-9)

Os grandes sistemas filosóficos equivocam-se, pois, ao invés de se voltarem para "as coisas que importa saber", buscam explicações sobre aquilo que é inacessível ao homem. "Todo problema da constituição de um sistema filosófico (...) reside, assim, na definição dos objetos aos quais se pode aplicar o raciocínio" observa André Charrak (2004, p. 20), que procura desenvolver um pouco mais a discussão sobre a influência de Descartes em Rousseau realizada por Gouhier (2005).

Segundo Charrak, o interesse pela aplicação eficaz da razão, assim como as condições de tal aplicação, é um ponto fundamental na leitura de Descartes por Rousseau. Trata-se de mobilizar as noções e as faculdades convenientes para o conhecimento de cada objeto e das propriedades, tal como defende Descartes na Carta a Elisabeth de 21 de maio de 1643 (apud CHARRAK, 2004, p. 22):

Eu considero também que toda a ciência dos homens não consiste senão em distinguir bem essas noções, e a atribuir a cada uma delas apenas as coisas que elas possuem. Pois quando nós queremos explicar alguma dificuldade por meio de uma noção que não lhe pertence, não falhamos em nos enganar.

Rousseau lança mão desses conhecidos argumentos cartesianos para se dirigir contra os materialistas, os quais confundem julgamento com sensação e atribuem o pensamento à matéria (cf. CHARRAK, 2004). Diferentemente de 
Religare, ISSN: 19826605, v.15, n.2, dezembro de 2018, p.548-569.

Descartes, entretanto, a metafísica do Vigário não gira em torno da veracidade daquilo que existe, ou da existência de si mesmo ${ }^{14}$ :

Em nenhum momento o Vigário se pergunta se o mundo exterior existe. Em um instante ele nos dirá que aos seus olhos semelhante problema não significa nada; de fato, Condillac o dispensou da questão à qual Descartes finalmente respondeu sim na última etapa de seu itinerário metafísico, e a qual Berkeley, desde a primeira, tinha respondido não. (GOUHIER, 2005, p. 68)

Descartes procura uma certeza indubitável para a afirmação "isso existe". As questões que sua metafísica procura responder giram em torno, portanto, da existência tanto das coisas sensíveis como de si mesmo. Para o Vigário, essas questões não são difíceis de responder afirmativamente ${ }^{15}$. O problema da existência ou não do mundo e de si mesmo não representa para ele um problema filosófico, pois quando o padre questiona-se sobre sua existência, a pergunta não é “eu existo?", mas "quem sou eu?", pergunta que é seguida rapidamente pela resposta: "Eu existo e tenho sentidos pelos quais sou afetado. Eis a primeira verdade que me atinge e com a qual sou forçado a concordar" (OC IV, p. 570). A existência de si mesmo é dada como um fato; a "primeira verdade" do Vigário

\footnotetext{
${ }^{14}$ Conforme exposto mais acima, os temas principais da metafísica do Vigário são a existência e a imortalidade da alma, a liberdade e a existência do Deus bom e justo. Deve-se destacar que a definição desses temas denota o papel primordialmente moral da metafísica elaborada na Profissão de fé.

15 Ainda sobre os limites das semelhanças entre Descartes e o sistema filosófico do Vigário saboiano, é importante ressaltar as diferenças existentes no interior mesmo da reapropriação de alguns elementos do cartesianismo pelo genebrino. A primeira destas refere-se à causa da dúvida - que nos dois filósofos assume o caráter de uma dúvida metódica. Se, por um lado, as dúvidas do padre originam-se em um profundo abalo das suas convicções morais causado pela decepção com a vida social ao constatar a hipocrisia e os preconceitos dos homens, por outro, "a dúvida de Descartes é consequência de um fracasso na ordem do saber: na origem da revisão geral de suas opiniões existe a falência das ciências que ensinam nas escolas" (GOUHIER, 2005, p. 64).

Outra diferença entre os dois itinerários se refere à questão da evidência, pois os conhecimentos que o Vigário admite como evidentes são "todos aqueles a que, na sinceridade de meu coração, não possa recusar meu consentimento, como verdadeiros todos os que me pareçam ter uma ligação necessária com os primeiros" (OC IV, p. 570). Para Descartes, por sua vez, "a evidência é uma propriedade da coisa vista e não um estado do sujeito que vê; em outros termos, a evidência não é a certeza, mas o que no objeto produz a certeza no sujeito" (GOUHIER, 2005, p. 66). A certeza cartesiana é encontrada na razão impessoal e universal, já a do Vigário é estabelecida a partir do indivíduo.
} 
Religare, ISSN: 19826605, v.15, n.2, dezembro de 2018, p.548-569.

não é resultado, assim, de uma longa investigação filosófica, de uma dúvida que o inquietasse, mas deduzida facilmente através da confiança nos sentidos.

Para Rousseau, como já mencionado anteriormente, a dúvida que merece ser cuidadosamente resolvida refere-se à existência de Deus. Tarefa cujas dificuldades não deixam de ser assumidas pelo genebrino:

O Ser incompreensível que abarca tudo, que dá o movimento ao mundo e forma todo o sistema dos seres não é nem visível aos nossos olhos, nem palpável às nossas mãos; ele escapa a todos os nossos sentidos; a obra se mostra, mas o operário se esconde. Não é pouca coisa saber, enfim, que ele existe, e quando chegamos a isso, quando nos perguntamos: quem ele é? onde está?, nosso espírito se confunde, perde-se e já não sabemos o que pensar. (OC IV, p. 551)

Esses questionamentos que preparam a narrativa no Vigário saboiano introduzem a complexidade das dúvidas que deverão ser enfrentadas para a apreensão da "verdadeira filosofia". Pouco mais adiante (OC IV, p. 553), Rousseau expõe as difíceis questões que surgem quando se procura compreender a respeito do Ser que "dá movimento ao mundo", que são: a existência das duas substâncias, a distância entre essas substâncias e a natureza divina, e entre a “ideia incompreensível da ação de nossa alma sobre nosso corpo e a ideia da ação de Deus sobre todos os seres". Somam-se ainda "as ideias de criação, de aniquilação, de ubiquidade, de eternidade, de onipotência, a ideia dos atributos divinos".

Se essas noções não são obscuras para o povo, isso se deve ao fato de ele "não compreender absolutamente nada disso", da mesma forma que as crianças, ainda ocupadas "com as primeiras operações dos sentidos e que só concebem o que tocam" (OC IV, p. 553). Tais questões afetam apenas aqueles que já adentraram nos tortuosos caminhos da filosofia: "a palavra espírito não tem qualquer sentido para quem não tenha filosofado" (OC IV, p. 552). A própria concepção monoteísta do divino não poderia ter surgido sem o esforço intelectual que permite ao homem alcançar as ideias mais abstratas: “Os homens puderam 
Religare, ISSN: 19826605, v.15, n.2, dezembro de 2018, p.548-569.

reconhecer um só Deus apenas quando, generalizando cada vez mais suas ideias, tiveram condições de remontar a uma primeira causa, de reunir o sistema total dos seres sob uma só ideia e dar um sentido à palavra substância, que é no fundo a maior das abstrações" (OC IV, p. 553).

Rousseau já havia refletido, no Discurso sobre a desigualdade (OC III, p. 144), sobre "a distância entre as puras sensações e os mais simples conhecimentos" ao argumentar sobre a incapacidade do homem selvagem em realizar raciocínios abstratos. Sem nada que o motivasse a elaborar algum tipo de conhecimento que o afastasse do estado primitivo, o selvagem permanece extremamente ligado às sensações, "os primeiros instrumentos dos nossos conhecimentos" (OC IV, p. 552). Entretanto, quando o homem encontra-se afastado do seu estado original, o bom desenvolvimento da razão torna-se indispensável para a apreensão da verdade.

\section{Conclusão}

O grande êxito da Profissão de fé consistiria na apropriação de ideias resultadas do cuidadoso percurso intelectual que oferece, para o Vigário, uma resposta que ele julga ser a mais próxima da verdade. Quando o Vigário recusa assumir-se como filósofo, ele não está, certamente, rejeitando o papel reflexivo e questionador da filosofia. O ideal iluminista do sapere aude, elogiado por Kant, não parece ser esquecido na Profissão de fé, cuja tarefa primordial seria a de estabelecer, a partir de si mesmo, os princípios de um pensamento filosófico e religioso que estivessem de acordo com aquilo que Rousseau acredita representar uma manifestação da verdade.

Quando Rousseau aponta o caráter nocivo da razão, ele se refere ao mau uso que os homens fazem dela quando, movidos pelo orgulho e pela vaidade, procuram conhecer aquilo que foge à sua capacidade de conhecer. É por esse motivo que o Vigário limita suas buscas ao que realmente importa, ou seja, ao que tem influência sobre sua conduta moral; ele "não se resigna de forma alguma a 
Religare, ISSN: 19826605, v.15, n.2, dezembro de 2018, p.548-569.

ignorar o que lhe importa saber; sobre esse ponto lhe é necessária uma certeza" (DERATHÉ, 1948, p. 44).

Essa certeza será encontrada num perfeito acordo com as verdades expressas pela ordem da natureza. Se a ordem revela um Deus bom e justo, qualquer religião que pregue a intolerância, o ódio e a injustiça, não pode ser considerada como verdadeira. A racionalidade, princípio nunca desmentido pelas leis que regem a natureza, não deve igualmente ser contrariada pelas doutrinas religiosas. Este é o fundamento da crítica rousseauniana às religiões que sustentam suas crenças através dos testemunhos de milagres, ou ainda, ao dogma cristão de que é preciso crer num determinado Deus para ser salvo. Para o genebrino, qualquer traço de intolerância que decorra deste ou de outros dogmas deve ser prontamente repudiado.

Por fim, o bom uso da razão mostra mais uma vez seu caráter determinante quando se trata de escolher a religião a que pertencerá o jovem Emílio. Diante desse problema, Rousseau afirma que o pupilo de Jean-Jacques não será filiado "nem a esta, nem àquela religião", mas será posto "em condição de escolher aquela a que seja conduzido pelo melhor emprego da razão" (OC IV, p. 558). De certo, uma escolha que respeita as demais opiniões.

\section{Referências}

BERNARDI, Bruno. Présentation, notes, bibliographie et chronologie. In : ROUSSEAU, J.-J. Profession de foi du Vicaire savoyard. Paris : GF-Flammarion, 2010. BAYLE, Pierre. Dicionário Histórico e Crítico. Tradução: Plínio Junqueira Smith. In: Sképsis, ano I, n²2, 2007. pp. 149-169.

BRÉHIER, Émile. Les lectures malebranchistes de Jean-Jacques Rousseau. In. : Études de Philosophie Moderne. Paris : Presses Universitaires de France, 1965. pp. 84-100.

BURGELIN, P. Notes et variantes (Émile ou De l'éducation). In: Oeuvres complètes de Jean-Jacques Rousseau. Bibliothèque de la Pléiade, Tome IV, Paris, Gallimard, 1969.

BURGELIN, Pierre. La philosophie de l'existence de Jean-Jacques Rousseau. Seconde édition, Paris : Librairie Philosophique J. Vrin, 1973. 
Religare, ISSN: 19826605, v.15, n.2, dezembro de 2018, p.548-569.

CHARLES, Sébastien. Rousseau e o ceticismo das Luzes. In: Rousseau e o iluminismo / Genildo Ferreira da Silva (Org.). Salvador: Arcádia, 2009.

CHARRAK, André. Descartes et Rousseau, in CHARRAK, A. et SALEM, J. (éds), Rousseau et la philosophie, Paris : Publications de la Sorbonne, 2004.

DERATHÉ, R. Le Rationalisme de Jean-Jacques Rousseau. Paris: Presses Universitaires de France, 1948.

DESCARTES, R. Discurso do método. Col. Os Pensadores, São Paulo: ed. Abril Cultural, 1983.

GOUHIER, Henri. Les Méditations Méthaphysiques de Jean-Jacques Rousseau. Paris : Librairie Philosophique J. Vrin, 2005.

KAWAUCHE, Thomaz Massadi Teixeira. Religião e política em Rousseau. Tese (doutorado em Filosofia), Faculdade de Filosofia, Letras e Ciências Humanas Universidade de São Paulo, 2012.

MASSON, Pierre-Maurice. La Religion de J.J. Rousseau : La formation religieuse de Rousseau. Paris : Librairie Hachette, 1916.

OLASO, Ezequiel de. Los Dos Escepticismo del Vicario Saboyano. In Manuscrito: Revista de Filosofia do Centro de Lógica, Epistemologia e História da Ciência da Universidade Estadual de Campinas, Vol.III, N.o 2, 1980.

ROUSSEAU, J.-J. Oeuvres complètes. Bibliothèque de la Pléiade, 5 vols., Paris : Gallimard, 1959-1995.

ROUSSEAU, J.-J. Ensaio sobre a origem das línguas. Trad. Fulvia Moretto. Campinas, SP : Editora da UNICAMP, 1998.

VINCENTI, Luc. L'idée de bonheur dans la pensée de Rousseau. In : A. Schnell (dir.). Le bonheur, Paris, Vrin, 2006. pp. 79-101.

Recebido em 28-08-2018.

Aprovado em 20-01-2019. 